\title{
Team collaboration capabilities as a factor in startup success
}

\author{
Anna K. Lopez Hernandez ${ }^{1^{*}}$, Anabel Fernandez-Mesa $a^{2}$, Monica Edwards-Schachter ${ }^{1}$,
}

\begin{abstract}
This paper discusses the role of team collaboration as a building block for cultivating capabilities in technology-based startups. This conceptual framework draws on a literature review of innovation and entrepreneurship research to understand the intra-organization collaboration mechanisms among team members in technology-based startups. Introducing the concept of team collaboration capabilities represents a new approach to understanding the interaction conditions that give rise to new capabilities from a venture team as its organizational base. Rapid new capability building represents a competitive advantage in environments characterized by innovative technological change, known as dynamic capabilities.
\end{abstract}

Keywords: Technology-based startup team; technology-based startups; team collaboration capabilities; dynamic capabilities; collaboration; capability building

Submitted: July $12^{\text {th }}, 2018 /$ Approved: November $6^{\text {th }}, 2018$

\section{Team collaboration capabilities: issues and gaps}

The purpose of this paper is to connect, through entrepreneurship and innovation management literature, the introduction and justification of team collaboration capabilities as a new approach to understanding dynamic capability building as an outcome of interaction conditions within the organization of technology-based startups. The complexity of the concept requires the integration of various microdimensional conceptual layers that must be aligned to understand the factors that affect collaboration in the organization of small-scale technology-based startups. We describe and explain the term team collaboration capabilities grounded on the origin, purpose, and composition of technology-based startup teams, as their essential organizational basis.

The framework for this study is dynamic capabilities. Dynamic capabilities are the antecedents of organizational and strategic routines, focusing on the fast-track reconfiguration of resources in the firm. Dynamic capabilities have attracted extensive scholarly attention in large firms in relation to inter-organizational collaboration, in which teams and organizations coordinate a range of processes such as the supply chain, commerce, and distribution, among others; researchers have also explored this collaboration under extraordinary conditions such as mergers and acquisitions in innovation environments. Dynamic capabilities also explain how firms generate new value-creation through strategies in rapid technological change contexts (Teece et al., 1997; Eisenhardt \& Martin, 2000)shaped by the firm's (specific. However, there is little research on the micro foundational processes of capability building, particularly in technology-based startups in the entrepreneurship literature. Technology-based startups are dynamic firms that represent organizations with entrepreneurial activities founded on the results of scientific and technical research and fieldwork. To date, the role of the team in technology-based startups has attracted little interest in the entrepreneurial research, even though teams are regarded as the essential condition of this type of organization, especially in the way they develop unique capabilities that allow the firm to create and maintain a competitive advantage.

Due to their high degree of novelty and disruption, launching the products and services of a technology-based startup demands intense and continuous work on international activities in often uncertain conditions. At the same time, the internal activities of the technologybased startup team involve coordinated group work; they constitute the essence of interaction generated by the internal and external collaborative work the team's members carry out. This collaborative team work in a technology-based startup drives the success of innovative projects (Hoegl \& Gemuenden, 2001)that \"good teamworkl" increases the success of innovative projects, raises new questions: What is teamwork, and how can it be measured? Why and how is teamwork related to the success of innovative projects? How strong is the relation- ship between teamwork and various measures of project success such as performance or team member satisfaction? This article develops a comprehensive concept of the collaboration in teams, called Teamwork Quality (TWQ. The members of a technology-based startup team deal with a high level of technological knowledge, which enables them to attain a high level of capabilities. In this respect, the concentrated, diverse and continual exchange of activities combine sophisticated knowledge, in which aspects such as trust, communication, problem-solving and team efficacy frequently play a relevant role. (Khan et al., 2014)it investigates the interaction effects of LOC diversity and affective trust on the internal LOC-performance relationship. Design/methodology/approach - Data originated from 44 entrepreneurial teams based in nine business incubators in Austria. Partial least squares (PLS. Hence the importance of studying the functions of technology-based startup teams as a necessary factor in understanding their internal innovation development processes, considering the key two-faceted nature of team collaboration: first, to strengthen and protect the firm's internal processes in developing innovation; and second, to prevent external failure caused by lack of cohesion efforts from inhibiting the innovation's progress.

(1) INGENIO (CSIC-UPV), Universitat Politècnica de València, Valencia, Spain

(2) Departamento de Dirección de Empresas “Juan José Renau Piqueras", Facultad de Economia, Universitat de València, Valencia, Spain *Corresponding author: anloher3@doctor.upv.es 
The conditions of technology-based startup teams demand the intense involvement of their members in collaboration. Here, the complexity of building new capabilities coexists with exploitation of existing basic capabilities to adapt the organization for survival in conditions of extreme pressure. This paper focuses on the phenomenon of technology-based startup teams in an attempt to provide a different approach to the team members' interactive role--defined as team collaboration capabilities--as a different micro-foundation perspective of dynamic capabilities. The paper takes the following structure: Section 2 introduces a definition of technology-based startups and two fundamental multidimensional aspects of their organization, namely, team-building conditions and team member characteristics. Section 3 introduces the conceptual framework we use to analyze the interrelationships between dynamic capabilities and collaboration as a condition for innovation that leads to the term team collaboration capabilities and its justification. Finally, Section 4 provides the conclusions.

\section{Fundamental concepts}

\subsection{Definition of Technology-Based Startups}

The term technology-based startup has been used to define small firms that develop and introduce new technology with a focus on invention, and technological advancements. The concept of technology-based startups is rooted in the entrepreneurship activities linked to a technology (Rammer, 2006). A technology-based startup in its early stages can experience difficulties in the complex processes of translating a "basic science invention" into a commercially viable international "innovation" (Auerswald \& Branscomb, 2007). Hence, the progression to global markets becomes intensely competitive and uncertain. This circumstance increases risks in technology-based ventures, which demand an intensification of development, improvement, and delivery of R\&D activities. Hart and Denison (1987, p. 512) define technology-based startups as "ventures that emphasize the role of research and development in the introduction of new products or services or as those that place their major strategic emphasis on the exploitation of technology in products, processes, or services" (Hart \& Denison, 1987, p.512). Technology-based startups are also perceived as young dynamic organizations that pursue an unknown business model in order to disrupt existing markets or create new ones, in which the founders attempt to capitalize on developing a product or service for which they believe there is a demand (Bhave, 1994).

One of the most cited definitions is that of Ries (2011, p.8), in his book The Lean Startup, where he refers to a startup as: "a human institution designed to create new products and services under conditions of extreme uncertainty". Technology-based startups can be classified according to the firm's conditions and technological inclination, for instance, the case of technology-based startups aiming to launch new applications of technology such as cleantech and renewable energy in green, ecological and sustainable markets (Bjornali \& Ellingsen, 2014). The new technological product-concept follows specific trends and must be identified in the market. Particularly, the ideas and concepts of technology-based startups focus on their mission to protect the environment and reduce impacts by facilitating the use of clean energy and environmentally friendly solutions.
The entrepreneurial nature of technology-based startups means they actively promote the launch onto the market of radical innovations in their products, business models, and distribution systems. Moreover, some technology-based startups have made attractive breakthroughs that are in great demand from industrial sectors, supported by processes that cover specific gaps in the industry and meet local regulations. For example, biomaterials can position them as essential to clean-cycling processes in the industry (Bjornali \& Ellingsen, 2014). Other authors have also referred to technology-based startups as technology-based ventures, defined as firmly grounded in new knowledge-based entrepreneurship (Bhave, 1994).

According to Paradkar et al. (2015), technology-based startups are managed by entrepreneurs who assess markets, technologies and business models in different ways, for example, by attempting to introduce new products and influence the market by promoting customers' values of awareness in comparison to existing products. Also, these entrepreneurial firms exploit their own ideas, or adapt and integrate ideas of others, to change new or existing assets into meaningful and value-added configurations. The efficiency of a technology-based startup team constantly shapes the organization's functions, where key activities are orchestrated to support the delivery of R\&D in new prototype products and, by testing sophisticated services, to determine the strategic market direction (Cohen \& Bailey, 1997). Thus, technology-based startups are firms that disturb the status quo of established firms, disrupting and altering traditional patterns of behavior with fresh ways of doing things (Teece et al., 1997; Paradkar et al., 2015).

\subsection{Team definition and foundation}

The organization of technology-based startups is based on a team, which is frequently referred to as a top management team, an entrepreneurial team, a new venture teams, a founding team, a startup team and a technology-based team. The concept of team in technology-based startups involves an entrepreneurial and innovation team organization, which usually emerges within, from, across or outside a firm or institution, such as a university, research institution or industry (Harper, 2008). The internal conditions of technology-based startup team are entrenched with continual collaboration as Hoegl and Gemuenden (2001, p. 436)that \"good teamwork〉" increases the success of innovative projects, raises new questions: What is teamwork, and how can it be measured? Why and how is teamwork related to the success of innovative projects? How strong is the relation- ship between teamwork and various measures of project success such as performance or team member satisfaction? This article develops a comprehensive concept of the collaboration in teams, called Teamwork Quality (TWQ describe: “... a social system of three or more people, which is embedded in an organization (context), whose members perceive themselves as such and are perceived as members by others (identity), and who collaborate on a common task". The concept of the team can be explained by taking into account attributes such as complexity, adaptive capacity, and dynamism (Ilgen et al., 2005) in a context that relates to the entities to which they belong. 
Cooney (2005) defines an entrepreneurial team as "two or more individuals who have a significant financial interest and participate actively in the development of the enterprise" (p.229). Cooney's definition is, however, quite broad to define the startup of a business. Notwithstanding, the real value teams add to technology-based startups is based on their activities and expertise, which as a whole pursues innovation with a financial interest, and in return recognition is expected to translate into business profits. The founders are individuals that take part in an entrepreneurial venture and constitute the human capital and valuable resources of the technology-based startup team. Harper (2008) highlights the role of a common goal, defining an entrepreneurial team as "a group of entrepreneurs with a common goal that can only be achieved by appropriated combinations of individual entrepreneurial actions" (p.614). It is worth noting that the entrepreneurial team could emerge within, across or outside another firm or institution as result of networking by one or more of the founders.

A more extended definition proposed by Schjoedt and Kraus (2009) maintains that: "An entrepreneurial team consists of two or more persons who have an interest, both financial and otherwise, in and commitment to a venture's future and success; whose work is interdependent in the pursuit of common goals and venture success; who are accountable to the entrepreneurial team and for the venture; who are considered to be at the executive level with executive responsibility in the early phases of the venture, including founding and pre- start up; and who are seen as a social entity by themselves and by others." (p.515). This definition emphasizes the pursuit of common responsibilities in objectives and the management of the team and infers a level of equity among the members in regard to the team's performance.

Moreover, further definitions reveal that a 'new venture team' is described as "the group of individuals that is chiefly responsible for the strategic decision making and ongoing operations of a new venture" (Klotz et al., 2014, p.227). Ideally, all the team members should 'actively' participate and contribute to the development of the organization and implementing operations. Specifically, team members define the guidelines of the business plan and strategy, organize the vision and mission of the technology-based startup, attract investment and recruit talent, among other activities (Klotz et al., 2014).

\subsection{Team members' characteristics}

The foundation of a technology-based startup team begins around an idea that has already been formed. The creation of the team and group development always take place within a specific context or "ecosystem" (Hart \& Denison, 1987). The creation of a technologybased startup team can take place in universities, and private and public laboratories, and usually occur in environments that incubate and nurture technical expertise. Hart and Denison (1987) note that systemic technology conditions determined by institutions and the social context foster the formation and existence of entrepreneurs and the creation of startup teams. In other words, the environment works as a conglomerate of academia, science, finance and training, which are sources that attract and provide the conditions for and availability of highly-qualified technical and scientific human resources. Further, the proximity of the ecosystem in innovation environments increases the chances for technology transfer, seeding new ideas and organizational capabilities for new business opportunities.

The literature shows that criteria for recruiting technology-based startup team members include experience, educational level, previous work experience, affiliation background (university, company), and prior success (Colombo \& Piva, 2012). Several researchers observe that diversity of points of view stimulates and contributes to building creative processes such as linking ideas, performing tasks, designing solutions, and organizational structures. Specific team characteristics studied in the entrepreneurial and management literature include team composition, shared personal and professional objectives, professional recognition such as merits, and organizational support and trust (Khan et al., 2014)it investigates the interaction effects of LOC diversity and affective trust on the internal LOC-performance relationship. Design/methodology/approach - Data originated from 44 entrepreneurial teams based in nine business incubators in Austria. Partial least squares (PLS. The interplay for building capabilities requires leadership, management and team members as its human capital, in which formal, codified or explicit knowledge (cognition) is the firm's dominant core logic.

The technology-based startup team requires a stock of human capital directly related to individual skills. The term skills encompasses traits, knowledge, previous experiences and abilities that should be 'orchestrated' between the team's members to shape both the individual and organizational capabilities, linked to the strategy and performance (Azagra-Caro et al., 2017). Highly-skilled team members become the technology-based startup team's human capital, which refers to individuals as sources of knowledge that obtain and develop new skills and expertise through education, training and previous work experience (Attewell, 1999). However, highly-skilled human capital is still not widely appreciated in private sectors, despite the fact that its participation in technological innovation activities represents a significant source of profit. The team depends on the motivation and commitment of its members, who should know and trust each other enough to share the same goals, intention, responsibility and decision making to start a company (Vyakarnam et al., 1999). The formation and professionalization of the team consolidate over time; moreover, it nourishes its dynamic with the intervention of new members and the growth of the organization.

Within the technology-based startup team, its members must define their roles, which include a range of tasks and relationships where aspects like trust are crucial. The entrepreneurs themselves have to legitimize their roles within the 'micro realm' of their organization as part of the social system by conforming to existing images and stereotypes, and by defining their own rights and duties. Management of the technology-based startup team is influenced by the active interaction and integration of the team members with the firm's other resources, and their responsibilities are defined according to their scientific and technical backgrounds (Klotz et al., 2014). Technology-based startup teams are shaped according to their innovation needs and are nourished by their ecosystem, through interaction with external actors, 
especially intermediaries, that facilitate resources to support innovation. Such intermediaries include government agencies, incubators, accelerators, and investors. Various authors also highlight the positive relationship between their operational autonomy and their organizational and strategic performance (Srivastava et al., 2006).

\section{Conceptual framework}

\subsection{Dynamic Capabilities and Collaboration}

In innovation environments, collaboration and dynamic capabilities are integrated as an essential condition among different organizations and firms. On the one hand, collaboration for innovation involves complex activities that require a combination of inputs from diverse sources. Collaboration involves different dimensions between individuals, the organization, the team and firms, which may be partners, suppliers or competitors. It implies that all the actors involved contribute with sources and know-how, also as complementary assets and capabilities, together sharing costs and risks for a common aim (Dodgson \& Rothwell, 1994). In a technology-based startup, collaboration represents interaction among individuals inside the organization where everyone works together to achieve a clear and shared aim in a specific context. On the other hand, the term dynamic capabilities is complex and controversial, which has therefore led to some disagreement over the concept among experts. Our review analyzed articles focused on the definition and origins of dynamic capabilities from the description of organizational conditions framed by collaboration activities. Teece and Pisano define dynamic capabilities as "the firm's ability to integrate, build, and reconfigure internal and external resources to address and shape rapidly changing business environments" (Teece \& Pisano, 1994). Dynamic capabilities aim to explain how a firm addresses turbulent market conditions by extending, modifying and reconfiguring existing operational capabilities to better match uncertain contextual conditions. In essence, resources and capabilities are built into the firm.

There are two streams of dynamic capabilities that aim to explain the organizational benefits to deploy the firm's resource base in a strategic way. The first is to determine which resources and capacities produce sustainable competitive advantages; and the second is to identify and assess them. Dynamic capabilities gain insight into different dimensions by examining the resource base of large firms; we look for definitions that conceive teams as the core of the organization. Some academics attribute the possession of a high level of resource base to explain how certain firms achieve and maintain their competitive advantage in contexts of rapid technological change (Teece et al., 1997). Dynamic capabilities constitute an explanation of how exceptional organizational abilities are built through time to survive in turbulent market conditions.

The internal factors that affect dynamic capabilities, according to Bowman and Ambrosini (2009), include (1) managers, (2) position and trajectory, (3) social capital, (4) leadership and (5) and trust. According to these factors, the manager's role depends heavily on his or her individual expertise to harmonize the firm's resources and operations in order to adapt it to the immediate circumstances. In terms of innovation management, one of the main aspects of managerial responsibilities is the development of dynamic capabilities in the organization. Bowman and Ambrosini (2009) propose that dynamic capabilities emerge from the co-evolution of the processes coming from the accumulation of tacit experience with the articulation and encoding of activities of explicit knowledge.

In this respect, complex and diverse collective efforts are concentrated in the technology-based startup teams' internal functions. These efforts are made by two or more individuals who interact with each other and with external actors from within their ecosystem, hold and share responsibility for the firm, and actively influence strategic decisions (Sapienza et al., 2006; Harper, 2008; Khan et al., 2014). Hence, the team's efforts focus mainly on innovation activities, so the team is an organizational 'mechanism' that combines diverse expertise and skills from individuals who have agreed to perform specific tasks in coordination with others, under complex and uncertain conditions, to achieve their objectives (Hoegl \& Gemuenden, 2001).

Collaboration and dynamic capabilities are not implicitly integrated concepts; however, the term itself implies that dynamic capabilities at inter- and intra-organizational level demand the tight integration of other synergies that involve 'collaboration' (Blomqvist \& Levy, 2006). We conducted a literature search to gain insight on various dimensions by examining reviews of dynamic capabilities to identify collaboration and interaction as essential factors of new capability building (see Table 1).

Table 1. Published reviews on the concept of dynamic capabilities based on team members' interaction or collaboration.

\begin{tabular}{|c|c|c|c|c|}
\hline Year & Author/s & Title & Journal name & Intra-team interactions/collaboration influences dynamic capabilities \\
\hline 2000 & $\begin{array}{l}\text { Deeds, DeCarolis, } \\
\text { and Coombs }\end{array}$ & $\begin{array}{l}\text { Dynamic capabilities and new } \\
\text { product development in high } \\
\text { technology ventures: An em- } \\
\text { pirical analysis of new biote- } \\
\text { chnology firms }\end{array}$ & $\begin{array}{l}\text { Journal of Busi- } \\
\text { ness Venturing, } 15 \\
(3), 211-229\end{array}$ & $\begin{array}{l}\text { "... what a high-tech venture needs is leadership that understands and has } \\
\text { experience in the new product development process, but is independent } \\
\text { and distinct from the scientific team. This kind of leadership maintains } \\
\text { the scientific team focused on research and development, and out of the } \\
\text { boards." (p. 212) } \\
\text { "According to dynamic capabilities theory, firms compile knowledge, expertise, } \\
\text { and skills through organizational learning. Learning capabilities enables firms } \\
\text { to perform their activities in improved ways. Organizational learning hap- } \\
\text { pens when their members interact with each other and develop common } \\
\text { codes of communication and coordination of activities. Furthermore, orga- } \\
\text { nizational learning is a dynamic activity, not only as an internal activity but } \\
\text { also as a result of the assimilation and use of knowledge generated outside } \\
\text { the firm." (pp.213-214) }\end{array}$ \\
\hline
\end{tabular}




\begin{tabular}{|c|c|c|c|c|}
\hline 2006 & $\begin{array}{l}2006 \text { Zahra, Sa- } \\
\text { pienza, and Davids- } \\
\text { son }\end{array}$ & $\begin{array}{l}\text { Entrepreneurship and dyna- } \\
\text { mic capabilities: A review, } \\
\text { model and research agenda. }\end{array}$ & $\begin{array}{l}\text { Journal of Mana- } \\
\text { gement Studies, } \\
43(4), 917-955 \text {. }\end{array}$ & $\begin{array}{l}\text { "...dynamic capabilities are affected by and transform substantive capa- } \\
\text { bilities and the firm's knowledge base. Together, the substantive capabi- } \\
\text { lities and the firm's knowledge base directly and interactively affect the } \\
\text { organization's performance. Finally, performance results affect future entre- } \\
\text { preneurial choices." (p.8) } \\
\text { "...substantive capabilities are embedded in what the firm does and how it } \\
\text { does it." (p.9) }\end{array}$ \\
\hline 2007 & Wang and Pervaiz & $\begin{array}{l}\text { Dynamic Capabilities: A Re- } \\
\text { view and Research Agenda. }\end{array}$ & $\begin{array}{l}\text { International } \\
\text { Journal of Mana- } \\
\text { gement Reviews } 9 \\
(1): 31-51 \text {. }\end{array}$ & $\begin{array}{l}\text { "...the firm's resources and capabilities in relation to environmental changes } \\
\text { and that allow for the identification of firm-specific or industry-specific pro- } \\
\text { cesses that are critical to the firm's evolution." (p.10) } \\
\text { Hence, capabilities are often firm-specific and are developed over time } \\
\text { through complex interactions among the firm's resources." (p.11) }\end{array}$ \\
\hline 2009 & $\begin{array}{l}\text { Bowman and Ambro- } \\
\text { sini }\end{array}$ & $\begin{array}{l}\text { What are dynamic capabilities } \\
\text { and are they a useful construct } \\
\text { in strategic management? }\end{array}$ & $\begin{array}{l}\text { International } \\
\text { Journal of Mana- } \\
\text { gement Reviews, } \\
11,29-49 .\end{array}$ & $\begin{array}{l}\text { "...the top management team and its beliefs about organizational evolution } \\
\text { may play an important role in developing dynamic capabilities." (p.2) } \\
\text { "The 'dynamism' relates to how the resource base changes in a new context } \\
\text { conditions through the use of dynamic capabilities. The dynamism consists } \\
\text { in the interaction of the dynamic capability and resource base, allowing } \\
\text { their modification respectively." (p.8) }\end{array}$ \\
\hline 2009 & $\begin{array}{l}\text { E a sterby-S mith, } \\
\text { Lyles, and Peteraf }\end{array}$ & $\begin{array}{l}\text { Dynamic capabilities: Current } \\
\text { debates and future directions. }\end{array}$ & $\begin{array}{l}\text { British Journal } \\
\text { of Manage- } \\
\text { ment, 20(s1), } \\
\text { S1-S8. }\end{array}$ & $\begin{array}{l}\text { "The operational mechanisms that influence new process development are } \\
\text { rooted in knowledge articulation and knowledge codification, and these re- } \\
\text { flect managerial decisions. Knowledge articulation can include managerial } \\
\text { decisions to have functionally diverse teams, which may include co-location } \\
\text { strategies to improve learning and problem-solving performance." (p.S5) } \\
\text { "...dynamic capabilities can take a variety of forms and involve different } \\
\text { functions, such as marketing, product development or process development, } \\
\text { but the overriding common characteristics are that they are higher level ca- } \\
\text { pabilities which provide opportunities for knowledge gathering and sharing, } \\
\text { continual updating of the operational processes, interaction with the envi- } \\
\text { ronment, and decision-making evaluations." (p.S7) }\end{array}$ \\
\hline
\end{tabular}

2009 Arend and Bromiley Assessing the dynamic capa- Strategic Organibilities view: spare change, zation 7(1) 75-90. everyone?.

"Scholars who examine organizational change generally agree that a variety of firm behaviors interact with the firm's condition and environment to influence the likelihood of performance-enhancing change." (p.82)

"The dynamic capabilities concept thus suggests greater tangibility and coherence in desirable features than the reality of complex, interacting firm behaviors. Firms may have the ability to do things they do not frequently do." (p.83)

2010 Barreto I. Dynamic capabilities: A re- Journal of Ma-
view of past research and nagement, 36(1), an agenda for the future. $\quad 256-280$.
The dynamic capabilities approach was built around "...several main elements that highlight its major theoretical underpinnings (nature, role, context, creation and development, outcome, and heterogeneity)."

"...specified the desired end (i.e., the role) of this special capability as being to integrate (or coordinate), build, and reconfigure internal and external capabilities. Herein, [Teece et al. (1997: 516)] they assumed an evolutionary economics perspective (Nelson \& Winter, 1982) by enunciating the role of routines, path dependencies, and organizational learning."(p.4)

\begin{tabular}{|c|c|c|c|c|c|c|c|c|c|c|}
\hline \multicolumn{2}{|l|}{2010} & & & & & & & $\begin{array}{l}\text { Dynamic Capabilities De- } \\
\text { constructed. A bibliographic } \\
\text { investigation into the origins, } \\
\text { development, and future di- } \\
\text { rections of the research do- } \\
\text { main. }\end{array}$ & $\begin{array}{l}\text { Industrial and } \\
\text { Corporate } \\
\text { Change, 19(4), } \\
1187-1204 .\end{array}$ & Not mentioned \\
\hline & & & & & 2012 & $\begin{array}{l}\text { Giudici and } \\
\text { moeller }\end{array}$ & Rein- & $\begin{array}{l}\text { Dynamic capabilities in the } \\
\text { dock: A case of reification? }\end{array}$ & $\begin{array}{l}\text { Strategic Orga- } \\
\text { nization, 10(4), } \\
436-449 .\end{array}$ & Not mentioned \\
\hline
\end{tabular}




\begin{tabular}{|c|c|c|c|c|}
\hline 2013 & Vogel and Güttel & $\begin{array}{l}\text { The dynamic capability view } \\
\text { in strategic management: A } \\
\text { bibliometric review. }\end{array}$ & $\begin{array}{l}\text { Internatio- } \\
\text { nal Journal of } \\
\text { Management } \\
\text { Reviews, } 15(4) \\
426-446 .\end{array}$ & $\begin{array}{l}\text { "Streamlining research in this field would lead to a better understanding of } \\
\text { the micro-foundations of dynamic capabilities. It would also help elucidate } \\
\text { the field's central theoretical concept, and thus consolidate the field's identity, } \\
\text { by drawing on (a) the interaction between top-management cognition, (b) } \\
\text { strategic decision-making and (c) routines and practices for reconfiguring } \\
\text { the firm's resource base." (pp.441). }\end{array}$ \\
\hline 2013 & $\begin{array}{l}\text { Peteraf, Di Stefano, } \\
\text { and Verona }\end{array}$ & $\begin{array}{l}\text { The elephant in the room of } \\
\text { dynamic capabilities: Bringing } \\
\text { two diverging conversations } \\
\text { together. }\end{array}$ & $\begin{array}{l}\text { Strategic } \\
\text { Management } \\
\text { Journal, 34(12), } \\
1389-1410 .\end{array}$ & Not mentioned \\
\hline 2013 & $\begin{array}{l}\text { Wilden, Devinney, } \\
\text { and Dowling }\end{array}$ & $\begin{array}{l}\text { The Architecture of Dynamic } \\
\text { Capability Research: A Scien- } \\
\text { tometric Investigation. }\end{array}$ & $\begin{array}{l}\text { Academy of Mana- } \\
\text { gement Procee- } \\
\text { dings (Vol. } 2013 \text {, } \\
\text { No. 1, p. } 11807\end{array}$ & Not mentioned \\
\hline 2016 & $\begin{array}{l}\text { Wilden, Devinney, } \\
\text { and Dowling despite } \\
\text { considerable acade- } \\
\text { mic interest, there are } \\
\text { many questions about } \\
\text { what dynamic capabi- } \\
\text { lities (DCs }\end{array}$ & $\begin{array}{l}\text { The Architecture of Dynamic } \\
\text { Capability Research Identi- } \\
\text { fying the Building Blocks of a } \\
\text { Configurational Approach. }\end{array}$ & $\begin{array}{l}\text { Academy of } \\
\text { Management } \\
\text { Annals, 10(1), } \\
997-1076 .\end{array}$ & $\begin{array}{l}\text { Dynamic Capabilities are essentially a multilevel phenomenon spanning in- } \\
\text { dividuals, groups [teams], business units, organizations, and alliances, and } \\
\text { that much of the definitional confusion arises from a failure to account } \\
\text { for the interactions across levels and between contexts."(p.1027) }\end{array}$ \\
\hline
\end{tabular}

Hence, collaboration under the dynamic capabilities framework emerges from the interaction and build-up of experience, skills and technical knowledge processes (Deeds et al., 2000), and depending on the firm's activity, it means based on "what the firm does and what it does it with" (Zahra et al., 2006); it involves changes in their environment that encourage the organization to evolve (Wang \& Ahmed, 2007); and entails a coordinated and active organizational condition of interaction with its context (Easterby-Smith et al., 2009). Hence, the organizational shift--dynamic capability--is fostered through the interaction of the firm's internal operational conditions with its context; in sum, through the tangibility of resources and consistency of continual efforts according to the circumstances (Arend \& Bromiley, 2009). Dynamic capabilities integrate internal and external collaboration activities in different dimensions of the firm, related to its operations, goals, context, processes of creation, development and outcome, by including the stakeholders in its ecosystem (Barreto, 2010). Finally, dynamic capabilities provide the framework for the understanding of a multilevel phenomenon that (1) arises from the interplay between top-management cognition, strategic decisionmaking and the incentive of flexible routines and coordinated practices (Vogel \& Güttel, 2013); (2) emphasizes intra-organizational (internal) and inter-organizational (external) collaboration through routines that allow the exchange of knowledge (Eriksson, 2014); and (3) is influenced by the context of the technology-based startup (Wilden et al., 2016).

Technology-based startup teams, as a social group, require the collection and integration of diverse activities and functions to consolidate the organization of the technology-based startup. These activities and functions can be exchangeable and specific, where each team member undertakes tasks that are distributed for operational purposes. For instance, in $\mathrm{R} \& \mathrm{D}$, new product development routines and quality control routines are shared and distributed among the available team members (Eisenhardt \& Martin, 2000)

The interaction among the members of the technology-based startup is crucial for its entrepreneurial activities and dynamic capabilities 
strategy. The team's dynamics support the perspective of harnessing the creativity and knowledge of each team member within the context of the startup. In this context, routines are predetermined, repetitive, specific, and standardized activities, such as those performed in production processes; interactions are more related to connectivity and coordinated contact (networking) with two or more members, taking into account their levels of intensity and frequency. Finally, sentiments are emotions, motivations, and attitudes that derive in the generation and adoption of knowledge and skills that cannot be measured but can have an impact upon both activities and interactions (Loasby, 2006).

When technology-based startup teams interact with their context, particular synergies are enabled among their members, and these forces create new inputs and processes (Ilgen et al., 2005). Technologybased startup teams usually arise from interactions among individuals with a background in high-technology industries (Vyakarnam et al., 1999). Their innovation functions and activities are closely related to the identification of opportunities for wealth and value creation. The technology-based startup teams' entrepreneurship activities require the willingness to identify opportunities by testing and checking processes and using their available resources efficiently. These conditions enable them to pursue a fast-track and dynamic adaptation and evolution of the team's organization by following the 'lean' concept (Ries, 2011). This adaptability and flexibility allow technology-based startup teams to work as an intermediary driver between the knowledge available and economic agents in the market.

\subsection{Team collaboration capabilities}

Collaboration capabilities support and strengthen organizational capabilities throughout the innovation process by improving the organization's performance. Collaborative capabilities are oversimplified under the dynamic capabilities approach, due to their interdependence with the company's internal resources. Collaboration in an organization focused on innovation involves the integration, coordination, and continuity of output-input activities between two or more actors (Blomqvist \& Levy, 2006). In contrast, capabilities in technology-based startups are a high-level routine or a set of routines developed for strategic purposes (Winter, 2003). Innovation is the result of collective and coordinated efforts produced by integrating and cross-leveling group interactions.

The team 'management performance' is an 'input-process-output' condition, characterized by a combination of autonomy, flexibility, mutual support, discipline, and trust among the team members. The manager needs to develop a high level of integration with the team. Collaborative capabilities consist of information processing, communication, knowledge transfer and control, where coordination, reliability or the ability to generate trust, and negotiation skills are vital (Blomqvist \& Levy, 2006, p.34). The team's members are vehicles of external and internal knowledge, produced and acquired through sharing in continuous interaction, and subsequently influencing the operational functions of the technologybased startup.
Team collaboration capabilities refers to the organization of technologybased startups, and centers on intra-organizational relationships at diverse levels of responsibility. It is a multidimensional concept comprising several levels of intra-team interaction, namely, individual (face-to-face), the team (a group of individuals), intra-firm coordination, and organizational collaboration for innovation (Blomqvist \& Levy, 2006). The interaction of team collaboration capabilities is also related to multidisciplinary teams, also known as cross-functional teams, which are more widely recognized in large companies and top team management activities, and involve collective and diverse efforts. Cross-functional teams "comprise a group of people representing a variety of [areas,] departments, disciplines, or functions, whose combined efforts [aim] to achieve the team's purpose". Once "[...]cross-functional teams [are effective, they] can speed up product development and turnaround on customer requests, improve the organization's ability to solve complex problems, serve as a vehicle for organizational learning and act as connecting points of contact for projects" (Wang \& He, 2008, p. 753). The effectiveness of crossfunctional teams depends on the interaction of a set of activities that facilitate learning, knowledge production, problem-solving and networking.

Most technology-based startups focus on international markets, and therefore collaboration in building new capabilities quickly is vital for their survival. Nevertheless, the conditions for building capabilities do not reach the same level of intensity and dynamic because other factors such as internal functions and needs must be considered and met. According to Zahra et al. (2006), the capabilities to transform and create new capabilities, dynamic capabilities, for innovation performance reside in the technology-based startup's origin, history and goals. Zahra et al. (2006) also identify the importance of the expertise and skills of the team's founder members as the key source of innovation, particularly if they contribute to transforming resources, considered as 'notably managerial resources' to foster new capability building. Dynamic capabilities therefore depend on the team's 'substantive capabilities' or operational capabilities, grounded in new additional knowledge as a result of the collective interaction of team members, based on the knowledge, activities and decision making linked to the strategy (Eisenhardt \& Martin, 2000; Zahra et al., 2006). The team's collaboration capabilities are their substantive ability to produce and support operative capabilities focused on, for example, new product development or distribution capabilities (Winter, 2003).

Team collaboration capabilities lie in the management and team members, through interaction and integration among the rest of the team members. The integration of the team allows the right combination of different skills and helps overcome resistance to change among members for organizational flexibility. (Clarke Højbjerg et al., 2014). Team collaboration capabilities link to the operational capabilities and encourage their continual improvement by adding high levels of new routines, and fast-tracking the configuration of new capabilities. Once operational activities are consolidated, operational capabilities continue to improve through dynamic capability building. However, they are a consequence of the unique idiosyncratic effects of the firm, namely the active willingness to learn and to adapt to new circumstances, even in highly dynamic environments. 


\section{Conclusions and future research}

The main objective of this paper was to explore the role of intra-collaboration functions as necessary conditions for dynamic capability building in technology-based startups. Through a combination of various literatures, we have articulated and exposed the term 'team collaboration capabilities' to describe the intra-organization collaboration sources required among the team members of technology-based startups. In light of our review, we propose a new definition of technology-based startups as follows: a technology-based startup is an organized team of two or more entrepreneurs with technical and/or scientific training, who share knowledge, responsibilities and active participation in the configuration of a team, from which new ideas are generated and responsibility is shared in taking operative and strategic decisions in order to sustain the organization in the long term.

Team collaboration capabilities incorporate the natural grouping of ideas and personal beliefs that team members have in common. The technology-based startup team is well characterized by important social and knowledge capital. From their beginning technologybased startup teams are made up of social capital that interacts with organizational assets and relational complementarities, for example, their personal relationships and professional networking activities. Moreover, a technology-based startup team implies knowledge heterogeneity and an organizational structure in their daily activities; this involves combining human capital with formal and informal connections for specific purposes. Together, these constitute a unique and differentiated firm structure defined by the technology-based startup team members' background and idiosyncrasies. The technology-based startup team's organization and operations forge each experience, knowledge, and skills to shape team expertise. The way in which individuals consistently work together defines, in part, the organization and its operational capabilities.

Dynamic capability building in technology-based startup teams is enabled through willing and positive behavior and the series of constant interactions that take place in team collaboration capabilities. They should produce good organizational outcomes as long as they work together and combine their individual skills. The technologybased startup team's activities, together with their coordinated interaction, are entrepreneurial components of their organization, which constitute drivers oriented to mobilizing the available resources, spotting new opportunities and assessing potential markets. Therefore, team collaboration capabilities engineer operational routines that together constitute the technology-based startup teams' dynamic capabilities.

We have attempted to bridge a gap in the literature on the internal processes of technology-based startup teams and their members' interaction in order to further current knowledge on dynamic capability building. This study represents an initial solid step to define a roadmap of the complex knowledge and recognition of team collaboration capabilities as a concept that describes the intra-team organizational conditions of the technology-based startup to support their role in innovation processes.
This study of technology-based startups has implications both for future research and for managers and investors (public and private). The main implications of this review lie in contrasting the dynamic capabilities approach with definitions of technology-based startups; although most of the papers reported were published in gray literature from the 1980s and 1990s, we also found several academic papers based on theoretical studies. In this respect, the technology-based startup team represents a co-evolutionary form of organization. Technology-based startup teams have a particularly dynamic organization that is highly ambivalent; it is a combination of independent and interdependent, an uncertain, fragile and dynamic form of organization. Within the organizational context of technology-based startups, the central agent is the interaction among the team's members, whose collaboration capabilities drive the firm's dynamic capabilities. Directions for future research include studies to provide a detailed analysis and assessment of team collaboration capabilities, considering the general interest of technology-based startups as unique and diverse organizations in continual adaptation.

\section{Acknowledgements}

We are grateful to the Consejo Nacional de Ciencia y Tecnología de México (CONACyT) for funding Anna Karina Lopez-Hernandez's Ph.D. research grant. We also thank the Conselleria d'Educació, Investigació, Cultura i Esport (GV/2018/003) for financial support for this research. We are indebted to Pablo D'Este for his detailed and insightful feedback.

\section{References}

Arend, R. J., \& Bromiley, P. (2009). Assessing the dynamic capabilities view: Spare change, everyone? Strategic Organization, 7(1), 75-90. https://doi.org/10.1177/1476127008100132

Attewell, P. (1999). What is Skill? Journal Work and Occupations, 17(4), 422-448. https://doi.org/0803973233

Auerswald, P. E., \& Branscomb, L. M. (2007). Collective Entrepreneurship Between Invention and Innovation. In Start-ups and Spinoffs (pp. 61-91). https://doi.org/10.1017/cbo9780511610134.004

Azagra-Caro, J. M., Barberá-Tomás, D., Edwards-Schachter, M., \& Tur, E. M. (2017). Dynamic interactions between university-industry knowledge transfer channels: A case study of the most highly cited academic patent. Research Policy, 46(2), 463-474. https://doi. org/10.1016/j.respol.2016.11.011

Barreto, I. (2010). Dynamic Capabilities: A Review of Past Research and an Agenda for the Future. Journal of Management, 36(1), 256280. https://doi.org/10.1177/0149206309350776

Bhave, M. P. (1994). A process model of entrepreneurial venture creation. Journal of Business Venturing, 9(3), 223-242.

Bjornali, E. S., \& Ellingsen, A. (2014). Factors Affecting the Development of Clean-tech Start-ups: A Literature Review. Energy Procedia, 58(1876), 43-50. https://doi.org/10.1016/j.egypro.2014.10.407 
Blomqvist, K., \& Levy, J. (2006). Collaboration capability-a focal concept in knowledge creation and collaborative innovation in networks. International Journal of Management Concepts ..., 2(1), 31-48. https://doi.org/10.1504/IJMCP.2006.009645

Bowman, C., \& Ambrosini, V. (2009). What Are Dynamic Capabilities and Are They a Useful Construct in Strategic Management? International Journal of Management Reviews, 11(1), 29-49. Retrieved from http://onlinelibrary.wiley.com/doi/10.1111/j.14682370.2008.00251.x/full

Clarke Højbjerg, A., Nissen Aarøe, H., \& Rostgaard Evald, M. (2014). Knowledge sharing in heterogeneous teams through collaboration and cooperation: Exemplified through Public-Private-Innovation partnerships. Industrial Marketing Management, 43(3), 473-482. https://doi.org/10.1016/j.indmarman.2013.12.015

Cohen, S. G., \& Bailey, D. (1997). What Makes Teams Work: Group Effectiveness Research from the Shop Floor to the Executive Suite. Journal of Management, 23(3), 239-290. https://doi. org/10.1177/014920639702300303

Colombo, M. G., \& Piva, E. (2012). Firms' genetic characteristics and competence-enlarging strategies: A comparison between academic and non-academic high-tech start-ups. Research Policy, 41(1), 79-92. https://doi.org/10.1016/j.respol.2011.08.010

Deeds, D. L., DeCarolis, D., \& Coombs, J. (2000). Dynamic capabilities and new product development in high technology ventures: An empirical analysis of new biotechnology firms. Journal of Business Venturing, 15(3), 211-229. https://doi.org/10.1016/S0883-9026(98)00013-5

Di Stefano, G., Peteraf, M., \& Veronay, G. (2010). Dynamic capabilities deconstructed: A bibliographic investigation into the origins, development, and future directions of the research domain. Industrial and Corporate Change, 19(4), 1187-1204. https://doi.org/10.1093/icc/dtq027

Dodgson, M., \& Rothwell, R. (1994). Technological collaboration and innovation. The Handbook of Industrial Innovation, 285-292. https:// doi.org/10.1093/oxfordhb/9780199694945.013.003

Easterby-Smith, M., Lyles, M. A., \& Peteraf, M. A. (2009). Dynamic capabilities: Current debates and future directions. British Journal of Management, 20(SUPP. 1). https://doi.org/10.1111/j.14678551.2008.00609.x

Ehrhardt, K., Miller, J. S., Freeman, S. J., \& Hom, P. W. (2014). Examining Project Commitment in Cross-Functional Teams: Antecedents and Relationship with Team Performance. Journal of Business and Psychology, 29(3), 443-461. https://doi.org/10.1007/s10869-013-9325-6

Eisenhardt, K. M., \& Martin, J. A. (2000). Dynamic Capabilities: What are They? Strategic Management Journal, 21(10/11), 1105-1121. Eriksson, T. (2014). Processes, antecedents and outcomes of dynamic capabilities. Scandinavian Journal of Management, 30(1), 65-82. https://doi.org/10.1016/j.scaman.2013.05.001
Giudici, A., \& Reinmoeller, P. (2012). Dynamic capabilities in the dock: A case of reification? Strategic Organization, 10(4), 436-449. https://doi.org/10.1177/1476127012457977

Harper, D. a. (2008). Towards a theory of entrepreneurial teams. Journal of Business Venturing, 23(6), 613-626. https://doi.org/10.1016/j. jbusvent.2008.01.002

Hart, S. L., \& Denison, D. R. (1987). Creating New technology-based organizations: A System Dynamic Model. Policy Studies, 6(3), 512528 .

Hoegl, M., \& Gemuenden, H. G. (2001). Teamwork Quality and the Success of Innovative Projects: A Theoretical Concept and Empirical Evidence. Organization Science, 12(4), 435-449. https://doi. org/10.1287/orsc.12.4.435.10635

Ilgen, D. R., Hollenbeck, J. R., Johnson, M., \& Jundt, D. (2005). Teams in organizations: from input-process-output models to IMOI models. Annual Review of Psychology, 56, 517-43. https://doi.org/10.1146/annurev.psych.56.091103.070250

Khan, M. S., Breitenecker, R. J. ., \& Schwarz, E. J. . (2014). Entrepreneurial team locus of control: diversity and trust. Management Decision, 52(6), 1057-1081. https://doi.org/10.1108/MD-06-2013-0349

Klotz, A. C., Hmieleski, K. M., Bradley, B. H., \& Busenitz, L. W. (2014). New Venture Teams: A Review of the Literature and Roadmap for Future Research. Journal of Management, 40(1), 226-255. https:// doi.org/10.1177/0149206313493325

Loasby, B. J. (2006). Microfoundations of Capabilities. DRUID Summer Conference 2006 on Knowledge, Innovation and Competitiviness: Dynamics of Firms, Networks, Regions and Institutions.

Paradkar, A., Knight, J., \& Hansen, P. (2015). Innovation in startups: Ideas filling the void or ideas devoid of resources and capabilities? Technovation, 41, 1-10. https://doi.org/10.1016/j.technovation.2015.03.004

Peteraf, M., Di Stefano, G., \& Verona, G. (2013). The elephant in the room of Dynamic Capabilities: bridging two diverhing conversations together. Strategic Management Journal, J(34), 1389-1410. https://doi. org/10.1002/smj.2078

Rammer, C. (2006). Technology-based start-ups. National Systems of Innovation in Comparison: Structure and Performance Indicators for Knowledge Societies, National S, 153-167. https://doi.org/10.1007/14020-4949-1_9

Ries, E. (2011). The Lean Startup How constant Innovation Creates Radically Successful businesses (First publ). London; New York: Penguin Group.

Rodan, S. (2002). Innovation and heterogeneous knowledge in managerial contact networks. Journal of Knowledge Management, 6(2), 152-163. https://doi.org/10.1108/13673270210424675 
Sapienza, H. J., Autio, E., George, G., Zahra, S. a, \& Harry, J. (2006). A Capabilities perspective on the Effects of Early Internationalization on Firm Survival and Growth. Academy of Management Review, 31(4), 914-933. https://doi.org/10.5465/amr.2006.22527465

Schjoedt, L., \& Kraus, S. (2009). Entrepreneurial teams: definition and performance factors. Management Research News, 32(6), 513524. https://doi.org/10.1108/01409170910962957

Srivastava, A., Bartol, K. M., \& Locke, E. A. (2006). Empowering Leadership in Management Teams: Effects on Knowledge Sharing, Efficacy,and Performance. Academy of Management Journal, 49(6), 1239-1251. https://doi.org/10.5465/AMJ.2006.23478718

Teece, D. J., \& Pisano, G. (1994). The dynamic capabilities of firms: An introduction. Industrial and Corporate Change, 3(3), 537-556. https://doi.org/10.1093/icc/3.3.537-a

Teece, D. J., Pisano, G., \& Shuen, A. (1997). Dynamic Capabilities and Strategic Management. Strategic Management Journal, 18(March), 509-533. https://doi.org/10.1002/(SICI)10970266(199708)18:7<509::AID-SMJ882>3.0.CO;2-Z

Vogel, R., \& Güttel, W. H. (2013). The dynamic capability view in strategic management: A bibliometric review. International Journal of Management Reviews, 15(4), 426-446. https://doi.org/10.1111/ ijmr. 12000
Vyakarnam, S., Jacobs, R., \& Handelberg, J. (1999). Exploring the formation of entrepreneurial teams: the key to rapid growth business? Journal of Small Business and Enterprise Development, 6(2), 153-165. https://doi.org/10.1108/EUM0000000006673

Wang, C. L., \& Ahmed, P. K. (2007). Dynamic capabilities: A review and research agenda. International Journal of Management Reviews, 9(1), 31-51. https://doi.org/10.1111/j.1468-2370.2007.00201.x

Wang, S., \& He, Y. (2008). Compensating Nondedicated CrossFunctional Teams. Organization Science, 19(5), 753-765.

Wilden, R., Devinney, T. M., \& Dowling, G. R. (2013). The Architecture of Dynamic Capability Research: A Scientometric Investigation. Academy of Management Proceedings, 2013(1), 11807-11807. https:// doi.org/10.5465/AMBPP.2013.11807abstract

Wilden, R., Devinney, T. M., \& Dowling, G. R. (2016). The Architecture of Dynamic Capability Research. Academy of Management Annals, 10(1), 997-1076. https://doi.org/10.1080/19416520.2016.1161966

Winter, S. G. (2003). Understanding Dynamic Capabilities. Strategic Management Journal, J(24), 991-995. https://doi.org/10.1002/smj.318

Zahra, S. A., Sapienza, H. J., \& Davidsson, P. (2006). Entrepreneurship and Dynamic Capabilities: A Review, Model and Research Agenda. Journal of Management Studies, 43(4), 917-955. https://doi. org/10.1111/j.1467-6486.2006.00616.x 
